8. Погрібний С. О. Механізм та принципи регулювання договірних відносин у цивільному праві України: дис. ... д-ра юрид. наук: 12.00.03. Київ, 2014. 412 с.

9. Сенюта І. Я. Цивільні правовідносини у сфері надання медичної допомоги в Україні: питання теорії і практики: дис. ... д-ра юрид. наук: 12.00.03. Київ, 2018. 500 с.

10. Таш'ян P. I. Механізм цивільно-правового регулювання транспортних відносин. Університетські наукові записки. 2016. № 57. C. $101-109$.

11. Федорченко Н. В. Зобов'язання з надання послуг у цивільному праві України: дис. ... д-ра юрид. наук: 12.00.03. Київ, 2015. 443 с.

12. Чернега В. М. Механізм сімейно-правового регулювання очима цивіліста-сучасника. Актуальні наукові дослідження сучасної юридичної науки: теорія та практика: зб. матер. ІІІ-ї Наук.практ.конф. (м. Київ, 18 березня 2016 р.). Київ: ВНЗ «Університет економіки та права «КРОК», 2016. С. 196-198.

13. Чефранова Е. А. Механизм семейно-правового регулирования имущественных отношений супругов: автореф. дисс. ... д-ра юрид. наук: 12.00.03. Москва, 2007. 54 с.

DOI https://doi.org/10.30525/978-9934-588-92-1-42

\title{
ДО ПИТАННЯ СТАНОВЛЕННЯ ІНСТИТУТУ СІМЕЙНОЇ МЕДІАЦІЇ В УКРАЇНІ
}

\author{
Широковська О. 0. \\ аспірант кафедри ичивільно-правових дисииплін \\ Національної академії внутрішніх справ \\ м. Київ, Україна
}

Одним із способів урегулювання спорів в Україні вважається звернення за допомогою до юрисдикційних органів. Проте на сьогодні сучасна судова система не здатна задовольнити в повному обсязі потреби всіх осіб, які вважають, що їх права порушено.

Крім того, часто ухвалення судового рішення не означає дійсного розв'язання конфлікту, а навпаки - провокує його ескалацію [1]. Значною мірою це стосується справ, що випливають із сімейних спорів. 
У зв'язку із зазначеним перед законодавчими органами нашої держави, а також правниками постає завдання щодо пошуку альтернативних (позасудових) способів вирішення приватно-правових спорів.

Саме сучасні запити суспільства зумовили появу медіації як новочасної форми залагодження правових спорів за допомогою нової культури діалогу із залученням посередників. Вона дає можливість не витрачати час на судовий розгляд, а також допомагає уникнути додаткових i непередбачуваних матеріальних витрат та надмірної заформалізованості процедури.

Медіація - це цивілізований процес вирішення проблем між сторонами на основі переговорів 3 участю нейтрального посередника (медіатора) [2]. Сімейна ж медіація передбачає застосування цього механізму, зважаючи на індивідуальність та унікальність кожної сім'ї, враховуючи при цьому емоційність й драматичність життєвої ситуації.

Пройшовши значний еволюційний шлях, медіація поступово сформувалася у такий спосіб подолання протиріч, що наділяє учасників відносин однаковими можливостями для реалізації власних прав та інтересів, забезпечує атмосферу, в якій сторони отримують взаєморозуміння, адже проводять спільну роботу над вивченням варіантів вирішення власних суперечок, дає можливість бути почутими й зрозумілими, економить енергію.

Дослідження окремих аспектів примирних процедур, у тому числі медіації, входило до кола інтересів вітчизняних та зарубіжних науковців, зокрема: С.С. Бичкової, Л.М. Дубчак, Х.Д. Алікперова, О.В. Аллахвердова, С.В. Бобровник, Д.К. Возьянова, Л.В. Головко, В.В. Землянської, Л. Фуллера, Х. Бесемера та інших.

Варто зазначити, що зарубіжні науковці, які досліджують альтернативне вирішення спорів, визначають в процесі медіації систематичність у докладенні зусиль кожного 3 подружжя, пошуку можливостей компромісів і консенсусів при вирішенні власних спорів та гуманності при з'ясуванні їхніх спільних та відмінних поглядів [3].

Як свідчить практика європейських країн, більшість процедур медіації завершуються успішно, і конфліктуючі сторони надалі не повертаються на шлях судового розв'язання спору [4, с. 42].

Але необхідно констатувати, що ця інституція в Україні тільки набуває обертів і поки не знайшла свого закріплення в національному законодавстві.

Доречно звернути увагу, що міжнародна практика застосування інституту примирення в багатьох країнах світу грунтується на позитивних результатах i надає безліч прикладів законодавчого закріплення медіації. 
Враховуючи те, що Україна підтверджує незмінність курсу на європейську інтеграцію, та погляди світового співтовариства, особливого значення набуває вивчення закордонного досвіду нормативного регулювання сімейної медіації як альтернативи судовим процедурам 3 метою підвищення якісного рівня українського законодавства й подальшої гармонізації національного законодавства із міжнародними стандартами, імплементації позитивних зарубіжних знань відповідного правового регулювання.

Досвід інших країн показує інтерес до діяльності й послуг медіаторів, що надають своїм клієнтам якісну допомогу, оскільки підвищують добробут їі громадян.

Однак законодавство нашої держави у контексті запровадження інституту сімейної медіації перебуває на початковій стадії розвитку, а отже, 3 огляду на вимоги часу, на цей час виникає необхідність вивчення та порівняння досвіду правового регулювання медіації в зарубіжних країнах, проведення наукового аналізу практичної складової, теоретичної, нормативної баз тощо, щоб надати йому певних інституційних рис й повноцінного розвитку на Батьківщині.

Станом на сьогодні в першому читанні в Україні прийнято довгоочікуваний законопроєкт «Про медіацію» № 3504, який було зареєстровано 19 травня 2020 року [5].

Разом $з$ тим сучасні процеси глобалізації обумовлюють гармонізацію та конвергенцію правових систем окремих країн світу, а тому вбачається необхідним ретельніше підходити до вивчення, аналізу досвіду законодавчого закріплення окресленої процедури задля уникнення імовірних помилок, проблем, які виникають при застосуванні вказаного інституту, й вироблення власних рекомендацій для подальшої реалізації міжнародних стандартів.

Незважаючи на наявність значної кількості наукових досліджень у цій сфері, питання імплементації зарубіжного досвіду у національне цивільне законодавство все ще залишається дискусійним.

Підсумовуючи вищевикладене, можна констатувати, що завдяки спільній співпраці фахівців-юристів, кваліфікованому підходу, а також подальшому прийняттю Закону України «Про медіацію» у перспективі нам вдасться максимально наблизити інститут медіації, в тому числі й сімейної, до потреб українського суспільства. Але тільки тоді він стане ефективним, якщо ми врахуємо при цьому значний європейський теоретичний і практичний досвід у сфері застосування альтернативного розв'язання спорів, закордонні стандарти та рекомендації міжнародних актів. 
Впровадження цього інституту надасть Україні унікальну можливість відійти від «ворожого» судового процесу, закладе підгрунтя для прогресивно вирішення правових конфліктів, сприятиме формуванню позитивного іміджу країни серед світової спільноти, оскільки, як стверджує В. Жмудь, заохочення людей до поваги один до одного та до вирішення конфліктів у разі їх виникнення на відновних засадах і за допомогою процедур примирення - це два найважливіших шляхи розбудови справедливого та гуманного суспільства [6, с. 25].

\section{Література:}

1. Иванов Е.Н. Место медиации в юридической практике // Развитие альтернативных форм разрешения правовых конфликтов в России: практика, проблемы, перспективы: тезисы участников Всерос. конф. 19-21 октября 1999 года. - Геленджик. [Электронный ресурс] Режим доступа: www.law-clinnic.ru/library.

2. Кузьмина М.Н. Медиация как альтернативная форма разрешения правовых конфликтов // Развитие альтернативных форм разрешения правовых конфликтов в России: практика, проблемы, перспективы: тезисы участников Всерос. конф. 19-21 октября 1999 года. Геленджик. [Электронный ресурс] - Режим доступа: www.lawclinnic.ru/library.

3. Rau A. Peppet S. Processes of dispute resolution. The role of Lawyers. Third edition / A. Rau, T. Sherman. - New York, 2002. - P. 337.

4. I. Orłowska Czy tylko mediacja między sprawcą a ofiarą // «Mediator»-nr. 20, 1/2202. - S. 42.

5. Про медіацію [Електронний ресурс]: проєкт Закону України від 19.05.2020, реєстр. № 3504. - Режим доступу: http:// www.rada.gov.ua.

6. Жмудь В. Запровадження процедури медіації (примирення) у законодавстві України // Відновне правосуддя в Україні. - 2008. № 2 (10). - С. 23-25. 